\begin{tabular}{ccc|} 
ISSN = 1980-993X - doi:10.4136/1980-993X \\
www.agro.unitau.br/ambi-agua \\
E-mail: ambi-agua@agro.unitau.br \\
Tel.: (12) 3625-4116
\end{tabular}

\title{
Production and properties of $\alpha$-amylase from Citrobacter species
} (doi:10.4136/ambi-agua.73)

\section{Justina Chibuogwu Orji ${ }^{1}$; Christian O. Nweke ${ }^{2}$; Rose N. Nwabueze ${ }^{3}$; Christopher E. Nwanyanwu $^{4}$; Chinwe S. Alisi ${ }^{5}$; Ebuta N. Etim-Osowo ${ }^{1}$}

\author{
Federal University of Technology, Owerri, Imo State, Nigéria \\ ${ }^{1}$ E-mail: chiookolo@yahoo.com \\ ${ }^{2}$ E-mail: xrisokey@yahoo.com \\ ${ }^{3}$ E-mail: r_n_nwabueze@yahoo.com \\ ${ }^{4}$ E-mail: cnwanyanwu2000@yahoo.com \\ ${ }^{5}$ E-mail: silverpresh@yahoo.com
}

\begin{abstract}
Amylase production by Citrobacter sp. isolated from potato was optimized in batch culture studies under shake flask conditions. Effects and interactions of best sources and levels of carbon and nitrogen estimated by $4 \times 5$ and $4 \times 4$ factorial experimental arrangements were significant $(\mathrm{P}<0.01)$ on amylase production. Optimal $\alpha$-amylase yield was obtained in a medium containing sorghum flour $(2.0 \% \mathrm{w} / \mathrm{v})$ and a mixture of $\left(\mathrm{NH}_{4}\right)_{2} \mathrm{SO}_{4}$ + soybean meal $(1.5 \% \mathrm{w} / \mathrm{v})$ with an initial medium $\mathrm{pH}$ of 8.0 . Under optimum conditions, amylase yield was maximal $(0.499 \mathrm{U} / \mathrm{ml})$ after $60 \mathrm{~h}$ incubation at room temperature $\left(28^{\circ} \mathrm{C} \pm\right.$ $2^{\circ} \mathrm{C}$ ). Characterization studies showed that the enzyme had maximum activity at $60^{\circ} \mathrm{C}$, retained $100 \%$ of its original activities at $60^{\circ} \mathrm{C}$ for $2 \mathrm{~h}$, was maximally active at $\mathrm{pH} 7.0$ and retained $100 \%$ of original activities at $\mathrm{pH} 9.0$ for $2 \mathrm{~h}$. Enzyme activity was stimulated by urea, $\mathrm{Mg}^{2+}, \mathrm{Ca}^{2+}$ and $\mathrm{Zn}^{2+}$ but inhibited by $\mathrm{Hg}^{2+}$.
\end{abstract}

Keywords: Citrobacter sp.; mixture of $\left(\mathrm{NH}_{4}\right)_{2} \mathrm{SO}_{4}$, soybean meal; sorghum flour.

\section{Produção de alfa-amilase a partir de Citrobacter spp}

\section{RESUMO}

A produção de amilase por Citrobacter sp. isolada a partir de batata foi otimizada pelo estudo de cultura em incubadoras com frascos rotativos. Efeitos e interações das melhores fontes e níveis de carbono e nitrogênio calculadas em desenhos experimentais fatoriais $4 \times 5 \mathrm{e}$ $4 \times 4$ foram significantes $(\mathrm{P}<0,01)$ para a produção de amilase. A produção ótima de alfaamilase foi obtida em um meio contendo farinha de sorgo $(2,0 \% \mathrm{~m} / \mathrm{v})$ e uma mistura de $\left(\mathrm{NH}_{4}\right)_{2} \mathrm{SO}_{4}+$ torta de soja $(1,5 \% \mathrm{~m} / \mathrm{v})$ com um pH médio inicial de 8,0. Em condições ótimas, a produção de amilase foi máxima $(0.499 \mathrm{U} / \mathrm{ml})$ após $60 \mathrm{~h}$ de incubação à temperatura ambiente $\left(28^{\circ} \mathrm{C} \pm 2^{\circ} \mathrm{C}\right)$. Estudos de caracterização mostraram que a enzima teve atividade máxima a $60^{\circ} \mathrm{C}$, quando reteve $100 \%$ de suas atividades originais por $2 \mathrm{~h}$, com $\mathrm{pH} 7,0$ e reteve $100 \%$ das atividades originais com $\mathrm{pH} 9,0$ por $2 \mathrm{~h}$. A atividade da enzima foi estimulada pela urea, por $\mathrm{Mg}^{2+}, \mathrm{Ca}^{2+}$ e $\mathrm{Zn}^{2+}$ mas, foi inibida por $\mathrm{Hg}^{2+}$.

Palavras-chave: Citrobacter sp.; $\left(\mathrm{NH}_{4}\right)_{2} \mathrm{SO}_{4}$, torta de soja; farinha de sorgo. 


\section{INTRODUCTION}

The fundamental idea in sustainable development is the provision of a framework for integration of economic, environmental and social development. In the industries, sustainability principles involve continuous innovation, improvement and use of clean technology to reduce pollution levels and consumption of resources (Lau and Jaworski, 2003). Bio-based industrial processes especially enzyme based technologies have been found to meet these demands through the elimination of the use of hazardous raw materials, reduction in energy consumption, production of emissions and by-products as well as in ensuring complete biodegradability of effluents (OECD, 2001). Due to their metabolic diversity, microorganisms and their products are a major resource in a bio-based economy.

The $\alpha$-amylase (1, 4- $\alpha$-D-glucan glucanohydrolase, EC 3.2.1.1) hydrolyses internal $\alpha-1,4$ glycosidic linkages in starch and related substrates (Bolton et al., 1997). Microbial amylases have found use in desizing of fabric to enhance good finishing in textile industry (Yoon, 2005), clean-up of drilling fluids during oil drilling, manufacture of cleaner biofuels from agricultural wastes, lowering toxic byproducts from pulp processing in paper industry, production of syrup, laundry and dish washing detergents (OECD, 2001). The enzyme has been demonstrated extracellularly in a wide variety of microorganisms such as members of the genera Lactobacillus (Ilori et al., 1996), Aspergillus (Obineme et al., 2003), and Bacillus (Uguru et al., 1997). However, Gram-positive bacteria and particularly the genus Bacillus are prolific amylase producers (Pandey et al., 2000). Despite their diverse applications, it is often difficult to find all the desirable attributes in an amylase produced by a naturally occurring microorganism. Special amylolytic attributes could be engineered into a microorganism, however, a necessary first step is the study of the production and characterization of amylases from naturally occurring amylolytic organisms to provide a pool for the selection. This is pertinent since the production requirements and characteristics of microbial amylases isolated from different sources vary (Pandey et al., 2000). This study was therefore designed to evaluate the amylolytic productivity of a Citrobacter sp. under different conditions, and characterize the enzyme produced under optimal conditions.

\section{MATERIAL AND METHODS}

\subsection{Isolation and screening of $\alpha$-amylase-producing microorganisms}

The organisms were isolated from rotten potato. Five gram of the rotten potato was weighed into $45 \mathrm{ml}$ sterile distilled water in a $250 \mathrm{ml}$ Erlenmeyer flask and shaken vigorously to suspend the organisms. The resultant suspension was serially diluted and $0.1 \mathrm{ml}$ of the $10^{-3}$ dilution was spread onto nutrient agar plates containing $1 \%(\mathrm{w} / \mathrm{v})$ soluble starch. The plates were incubated at room temperature $\left(28 \pm 2{ }^{\circ} \mathrm{C}\right)$ for $48 \mathrm{~h}$. Thereafter the colonies were purified by sub culturing onto fresh nutrient agar plates. The purified bacterial cultures were transferred into nutrient agar slants, incubated at room temperature for $48 \mathrm{~h}$ and thereafter stored in the refrigerator prior to screening.

Screening was done by point-inoculating the isolates on a medium which consisted of 2 $\mathrm{g} / 1\left(\mathrm{NH}_{4}\right)_{2} \mathrm{SO}_{4} ; 0.5 \mathrm{~g} / 1 \mathrm{MgSO}_{4} .7 \mathrm{H}_{2} \mathrm{O} ; 0.01 \mathrm{~g} / 1 \mathrm{FeSO}_{4} .7 \mathrm{H}_{2} \mathrm{O} ; 0.07 \mathrm{~g} / 1 \mathrm{~K}_{2} \mathrm{HPO}_{4} ; 10 \mathrm{~g} / 1$ Soluble starch and $17 \mathrm{~g} / \mathrm{l}$ agar in distilled water (Shaw et al.,1995). The medium was incubated at room temperature $\left(28 \pm 2^{\circ} \mathrm{C}\right)$ for $48 \mathrm{~h}$. Thereafter the plates were flooded with Gram's iodine solution $(0.1 \%(\mathrm{w} / \mathrm{v})$ Iodine crystals and $1 \%(\mathrm{w} / \mathrm{v})$ Potassium Iodide). Formation of clear zones around the colonies was suggestive of amylase production. The diameter of the zone of clearing was measured and the organisms with zones of clearing up to $1.0 \mathrm{~mm}$ were selected. 
One of the chosen organisms was identified as Citrobacter sp. using standard microbiological methods and scheme of Holt et al. (1994). This organism was used for further studies.

\subsection{Optimization of media for amylase production}

Optimization studies were done sequentially. Firstly, the effect of different carbon and nitrogen sources were studied together using a 4 x 4 factorial experimental layout. Thereafter, the effects of different concentrations of carbon and nitrogen combination that gave the highest amylase production were studied using a $4 \times 5$ factorial. Finally the effect of initial $\mathrm{pH}$ of medium on amylase production was studied.

The mineral salt medium hereafter referred to as basal salt medium (BSM) was adapted from Shaw et al. (1995) and consisted of $0.5 \mathrm{~g} / 1 \mathrm{MgSO}_{4} .7 \mathrm{H}_{2} \mathrm{O} ; 0.01 \mathrm{~g} / 1 \mathrm{FeSO}_{4} .7 \mathrm{H}_{2} \mathrm{O}$ and 0.07 $\mathrm{g} / \mathrm{l} \mathrm{K}_{2} \mathrm{HPO}_{4}$. For each study, the BSM was dispensed in $30 \mathrm{ml}$ volume into $100 \mathrm{ml}$ Erlenmeyer flasks while the carbon, nitrogen and $\mathrm{pH}$ were varied.

The carbon sources included crude carbon (sorghum and sweet potato flours) and purified carbon (soluble starch (Sigma)). The nitrogen sources included organic nitrogen (groundnut cake and soybean meal) and the inorganic nitrogen (ammonium sulphate (BDH)). The nitrogen sources were used alone or as a mixture in a 1:1 ratio.

The inoculum consisted of pure cultures of the organism grown on nutrient agar plates for 24 hours. The cells were introduced into sterile normal saline tubes and washed twice by centrifugation $(3000 \mathrm{rpm})$. Washed cells were resuspended in normal saline and standardized to obtain a cell suspension of approximately $600 \times 10^{6} \mathrm{cfu} / \mathrm{ml}$ using the McFarland standard of the nephelometry method (Campbell et al., 1970). One milliliter of this suspension was used as the inoculum in each flask.

For each study, fermentation lasted for $48 \mathrm{~h}$ at room temperature $\left(28 \pm 2^{\circ} \mathrm{C}\right)$ on a rotary incubator $(150 \mathrm{rpm})$. After fermentation, the supernatant recovered after centrifugation at $3000 \mathrm{rpm}$ and $4^{\circ} \mathrm{C}$ for 15 min was used as the enzyme source.

\subsection{Enzyme assay}

Amylase activity was estimated by the dinitrosalicyclic acid (DNS) method of Bernfeld (1955), using $0.5 \%(\mathrm{w} / \mathrm{v})$ soluble starch in $0.05 \mathrm{M}$ phosphate buffer (pH 6.0). One unit (U) of $\alpha$-amylase activity was defined as the amount of enzyme required to release one micromole of reducing sugar expressed as glucose per minute under the assay conditions.

\subsection{Time course for amylase production}

Time course for the production of $\alpha$-amylase was studied at room temperature $\left(28 \pm 2{ }^{\circ} \mathrm{C}\right)$ on a rotary incubator $(150 \mathrm{rpm})$ for $96 \mathrm{~h}$ using the most productive fermentation medium which consisted of BSM supplemented with sorghum flour $(2.0 \% \mathrm{w} / \mathrm{v})$, ammonium sulphate $\left.\left(\mathrm{NH}_{4}\right)_{2} \mathrm{SO}_{4}\right)+$ soybean meal $(1: 1)(1.5 \% \mathrm{w} / \mathrm{v})$ at an initial $\mathrm{pH}$ of 6.0 . Enzyme assays were done at intervals of $12 \mathrm{~h}$ after centrifugation as previously described.

\subsection{Characterization of enzyme}

The organism was grown for $60 \mathrm{~h}$ on the most productive fermentation medium whose composition was given above. Thereafter, the enzyme was harvested after centrifugation as previously described and then characterized. 


\subsection{Temperature activity and stability profiles}

The effect of temperature on enzyme activity was studied by measuring the amount of reducing sugar released during the reaction at different temperatures $\left(30-90^{\circ} \mathrm{C}\right)$. The reaction mixture consisted of $0.5 \mathrm{ml}$ each of the enzyme solution and $0.5 \%\left({ }^{\mathrm{w}} / \mathrm{v}\right)$ soluble starch in $0.05 \mathrm{M}$ phosphate buffer ( $\mathrm{pH}$ 6.0) incubated at the different temperatures for $30 \mathrm{~min}$. Thereafter, the reaction was stopped by the addition of $1 \mathrm{ml}$ of DNS reagent and enzyme activity determined as previously described Bernfeld (1955).

Thermal stabilities at $50^{\circ} \mathrm{C}, 60^{\circ} \mathrm{C}$ and $70^{\circ} \mathrm{C}$ were studied by incubating $0.5 \mathrm{ml}$ of the enzyme in thin walled test tubes at the various temperatures in a water bath incubator for $3 \mathrm{~h}$. At $30 \mathrm{~min}$ interval, one test tube from each temperature was withdrawn and cooled promptly on ice. At the end of $3 \mathrm{~h}$ the residual enzyme activity in the tubes were determined by the addition of $0.05 \mathrm{ml}$ of $0.5 \%\left({ }^{\mathrm{w}} / \mathrm{v}\right)$ soluble starch in $0.05 \mathrm{M}$ phosphate buffer, $\mathrm{pH} 6.0$ and incubating at $50^{\circ} \mathrm{C}$ for $30 \mathrm{~min}$. Reactions were stopped by the addition of 3,5-DNS reagent and enzyme activity determined.

\section{7. $\mathrm{pH}$ activity and stability profiles}

The effects of $\mathrm{pH}$ on amylase activity were studied using the following buffers: $(0.2 \mathrm{M})$ citrate phosphate buffer ( $\mathrm{pH} 3$ - 5), sodium phosphate buffer ( $\mathrm{pH} 6$ - 8) and sodium hydrogen carbonate- sodium hydroxide buffer ( $\mathrm{pH} 9-11)$.

The $\mathrm{pH}$ activity profile was determined in a reaction mixture consisting of $0.5 \mathrm{ml}$ each of the enzyme solution and $0.5 \%(\mathrm{w} / \mathrm{v})$ soluble starch prepared in buffers of the different $\mathrm{pH}$ values. The tubes were incubated at $50^{\circ} \mathrm{C}$ for $30 \mathrm{~min}$. The reaction was terminated by the addition of 3,5-DNS reagent and enzyme activities determined as described.

For the $\mathrm{pH}$ stability profile, test tubes containing $0.5 \mathrm{ml}$ enzyme and $0.5 \mathrm{ml}$ of the respective buffers of different $\mathrm{pH}$ values were incubated at room temperature $\left(28 \pm 2^{\circ} \mathrm{C}\right)$ for 2 h. Thereafter, enzyme activities were analyzed by the addition of $0.5 \mathrm{ml}$ of starch in $0.05 \mathrm{M}$ phosphate buffer $\left(\mathrm{pH} \mathrm{6.0)}\right.$ to each tube and incubated at $50^{\circ} \mathrm{C}$ for $30 \mathrm{~min}$. The reaction was terminated by the addition of 3,5-DNS reagent and enzyme activities determined as previously described.

\subsection{Effects of metal ions and enzyme modulators}

Metal ions which included $\mathrm{Ca}^{2+}, \mathrm{Ba}^{2+}, \mathrm{Co}^{2+}, \mathrm{Cu}^{2+}, \mathrm{K}^{+}, \mathrm{Fe}^{2+}, \mathrm{Ni}^{2+}, \mathrm{Zn}^{2+}, \mathrm{Na}^{+}$, at concentrations of $1 \mathrm{mM}$ each, and modulators, namely EDTA $(50 \mathrm{mM})$, Urea $(2 \mathrm{mM})$ and $\mathrm{HgCl}_{2}(1 \mathrm{mM})$, were tested for their effects on enzyme activity. The reaction mixture consisted of $0.5 \mathrm{ml}$ of enzyme and $0.5 \mathrm{ml}$ of the respective enzyme modulators or metal solutions in $0.05 \mathrm{M}$ phosphate buffer, $\mathrm{pH}$ 6.0. The reaction mixtures were left for $30 \mathrm{~min}$ at room temperature $\left(28 \pm 2{ }^{\circ} \mathrm{C}\right)$. Thereafter, $0.5 \mathrm{ml}$ of $0.05 \%\left({ }^{\mathrm{w}} / \mathrm{v}\right)$ soluble starch in $0.05 \mathrm{M}$ phosphate buffer, $\mathrm{pH} 6.0$, was added, and the mixture incubated at $50^{\circ} \mathrm{C}$ for $30 \mathrm{~min}$. The reaction was terminated by the addition of 3,5-DNS reagent and enzyme activities determined as previously described. Results were compared with a control treated in the same manner as the test but which contained the buffer in place of the solution of the metals or enzyme modulators.

\subsection{Analysis of findings}

Each experiment was carried out in triplicates. Data collected were subjected to analysis of variance (ANOVA) and the means separated using GenStat for Windows (GenStat, 2005). 
ORJI, J. C.; NWEKE, C. O.; NWABUEZE, R. N.; NWANYANWU, C. E.; ALISI, C. S.; ETIM-OSOWO, E. N. Production and properties of $\alpha$-amylase from Citrobacter species. Ambi-Agua, Taubaté, v. 4, n. 1, p. 45-57, 2009. (doi:10.4136/ambi-agua.73)

\section{RESULTS AND DISCUSSION}

The amylolytic organism identified as Citrobacter sp is a motile, Gram negative, citrate utilizing, indole negative and urease negative rod that ferments glucose and sucrose. The organism showed a zone of clearing of $1.2 \mathrm{~mm}$ in diameter on the screening medium. Amylolytic ability is widely distributed among several mesophilic microbial genera. However, only a few extracellular enzymes produced from Gram-negative mesophiles have been reported (Pandey et al., 2000). Members of the genus Citrobacter have not been reported to be prolifically amylolytic. Being a predominantly non-pathogenic soil resident, this organism lends itself amenable for use in the industrial production of amylases.

The effects of carbon source, nitrogen source and the interactions were significant $(\mathrm{P}<$ 0.01 ) on amylase production (Table 1). Within carbon sources, using soluble starch (pure) as the carbon source, significantly $(\mathrm{P}<0.01)$ lowest amylase yield $(0.071 \mathrm{U} / \mathrm{ml})$ was obtained when the purified inorganic $\left(\mathrm{NH}_{4}\right)_{2} \mathrm{SO}_{4}$ was used as the nitrogen source, compared with other sources of nitrogen. With cassava starch, there were no significant $(\mathrm{P}>0.01)$ differences between amylase yields $(0.285 \mathrm{U} / \mathrm{ml})$ due to a combination of $\left(\mathrm{NH}_{4}\right)_{2} \mathrm{SO}_{4}+$ groundnut cake or $\left(\mathrm{NH}_{4}\right)_{2} \mathrm{SO}_{4}+$ soybean meal as the nitrogen source, but the yields were significantly $(\mathrm{P}<0.01)$ greater than those obtained when either $\left(\mathrm{NH}_{4}\right)_{2} \mathrm{SO}_{4}$ or groundnut cake or soybean meal were used as the nitrogen source. Also, using sorghum flour, a combination of organic and inorganic nitrogen source was preferred to either organic or inorganic nitrogen as the nitrogen source.

Table1. Effects of different carbon and nitrogen sources on amylase production.

\begin{tabular}{|c|c|c|c|c|c|}
\hline \multirow{3}{*}{$\begin{array}{l}\text { Nitrogen sources } \\
(1 \% \mathrm{w} / \mathrm{v})\end{array}$} & \multicolumn{5}{|c|}{ Amylase activity (U/ml) } \\
\hline & \multicolumn{4}{|c|}{ Carbon sources (1\% w/v) } & \multirow[b]{2}{*}{ Mean } \\
\hline & $\begin{array}{l}\text { Soluble } \\
\text { starch } \\
\text { (pure) }\end{array}$ & $\begin{array}{c}\text { Cassava } \\
\text { starch } \\
\text { (crude) }\end{array}$ & $\begin{array}{c}\text { Sorghum } \\
\text { flour (crude) }\end{array}$ & $\begin{array}{l}\text { Sweet potato } \\
\text { flour (crude) }\end{array}$ & \\
\hline $\begin{array}{l}\left(\mathrm{NH}_{4}\right)_{2} \mathrm{SO}_{4} \\
\text { (Inorganic) }\end{array}$ & $0.071(5.31)$ & $0.107(5.55)$ & $0.142(4.69)$ & $0.214(5.13)$ & $0.134(5.17)$ \\
\hline $\begin{array}{l}\text { Groundnut cake } \\
\text { (Organic) }\end{array}$ & $0.249(4.78)$ & $0.071(5.61)$ & $0.249(4.73)$ & $0.178(4.84)$ & $0.187(4.99)$ \\
\hline $\begin{array}{l}\text { Soy bean meal } \\
\text { (Organic) }\end{array}$ & $0.107(4.61)$ & $0.178(4.46)$ & $0.214(4.35)$ & $0.249(4.64)$ & $0.187(4.52)$ \\
\hline $\begin{array}{l}\left(\mathrm{NH}_{4}\right)_{2} \mathrm{SO}_{4}+ \\
\text { groundnut cake }\end{array}$ & $0.142(4.92)$ & $0.285(4.75)$ & $0.285(4.62)$ & $0.285(4.59)$ & $0.249(4.72)$ \\
\hline $\begin{array}{l}\left(\mathrm{NH}_{4}\right)_{2} \mathrm{SO}_{4}+\text { soy bean } \\
\text { meal }\end{array}$ & $0.214(4.51)$ & $0.285(4.39)$ & $0.321(4.32)$ & $0.178(4.48)$ & $0.250(4.43)$ \\
\hline Mean & $0.157(4.83)$ & $0.185(4.95)$ & $0.242(4.54)$ & $0.221(4.74)$ & $0.201(4.77)$ \\
\hline
\end{tabular}

Basal medium contains the different combinations of the carbon and nitrogen sources. Initial media $p H=6.0$

Figures in parenthesis are final media $\mathrm{pH}$

$L S D_{0.01}$ for nitrogen source $=0.0092$

$L S D_{0.01}$ for carbon source $=0.0082$

$L S D_{0.01}$ for means of different nitrogen source at the same or different carbon source $=0.018$

Within nitrogen sources, using $\left(\mathrm{NH}_{4}\right)_{2} \mathrm{SO}_{4}$, lowest yield was obtained with soluble starch as the carbon source. With a combination of $\left(\mathrm{NH}_{4}\right)_{2} \mathrm{SO}_{4}+$ groundnut cake, there were no 
significant $(\mathrm{P}>0.01)$ differences in amylase yields $(0.285 \mathrm{U} / \mathrm{ml})$ obtained with either cassava starch, sorghum flour or sweet potato flour as the carbon source. However, these yields were significantly higher than the yield obtained with soluble starch as the carbon source. It thus appears that there is a preference for a combination of both organic and inorganic nutrient sources for optimal production of amylase by the organism. The requirement for the inclusion of crude nutrient sources could be attributed to the provision by the crude nutrients of other growth factors and ancillary substances which interacted significantly to influence enzyme production positively or negatively. The most significant negative interaction gave the lowest amylase yield of $0.071 \mathrm{U} / \mathrm{ml}$ observed in the treatment containing groundnut cake as the nitrogen source and cassava starch as the carbon source, while the most significant positive interaction gave the highest amylase yield of $0.321 \mathrm{U} / \mathrm{ml}$ obtained in the treatment containing a combination of $\left(\mathrm{NH}_{4}\right)_{2} \mathrm{SO}_{4}+$ soybean meal as the nitrogen source and sorghum flour as the carbon source. These nutrient sources were therefore considered optimal for enzyme production. Haq et al. (2002) also reported that both organic and inorganic nitrogen sources were essential for amylase production by Saccharomyces cerevisiae. The significant interaction between the carbon and nitrogen sources implies that the effects of one factor depended on the level of the other factor.

The final $\mathrm{pH}$ of the fermentation media varied (Table 1). However, in all the treatments, there were significant reductions in final media $\mathrm{pH}$ from the initial $\mathrm{pH}$ of 6.0. The final media $\mathrm{pH}$ of the treatment $\left(\left(\mathrm{NH}_{4}\right)_{2} \mathrm{SO}_{4}+\right.$ soybean meal $)+$ sorghum flour $)$ that gave the highest reduction in $\mathrm{pH}$ was 4.32 . Incidentally, this treatment also gave the highest enzyme yield. Likewise, the least reduction in $\mathrm{pH}$ (5.6) was also obtained in the treatment (groundnut cake + cassava starch) that gave the lowest enzyme yield. Further analysis of the amylase yield and final media $\mathrm{pH}$ of the various treatments showed that a negative correlation $(\mathrm{r}=-0.66)$ existed between the two parameters. It is therefore possible that $\mathrm{pH}$ plays a vital role in the interaction of the various carbon and nitrogen sources.

Further studies were done to determine the effects of levels of the optimal nutrients. Results presented in Table 2 shows that the effects of the different concentrations of sorghum flour as the carbon source, and a mixture of $\left(\mathrm{NH}_{4}\right)_{2} \mathrm{SO}_{4}+$ soybean meal as the nitrogen source, and their interactions were significant $(\mathrm{P}<0.01)$ on amylase production. At all the concentrations of sorghum flour, enzyme production increased with increasing concentration of the mixture of $\left(\mathrm{NH}_{4}\right)_{2} \mathrm{SO}_{4}+$ soybean meal, until a peak was reached, beyond which further increase in the concentration of the mixture of $\left(\mathrm{NH}_{4}\right)_{2} \mathrm{SO}_{4}+$ soybean meal led to a decrease in enzyme production. At the lower concentrations of sorghum flour $(0.5-1.0 \% \mathrm{w} / \mathrm{v})$, the peaks were obtained with $1 \% \mathrm{w} / \mathrm{v}\left(\mathrm{NH}_{4}\right)_{2} \mathrm{SO}_{4}+$ soybean meal while at the higher concentrations $(2.0-3.0 \% \mathrm{w} / \mathrm{v})$, the peaks were obtained with $1.5 \% \mathrm{w} / \mathrm{v}\left(\mathrm{NH}_{4}\right)_{2} \mathrm{SO}_{4}+$ soybean meal. These results suggest that amylase production respond to variations in the carbon: nitrogen ratios of the medium. The highest amylase yield of $0.427 \mathrm{U} / \mathrm{ml}$ was obtained at the respective concentrations of $1.5 \% \mathrm{w} / \mathrm{w}$ for the mixture of $\left(\mathrm{NH}_{4}\right)_{2} \mathrm{SO}_{4}+$ soy bean meal, and $2.0 \% \mathrm{w} / \mathrm{w}$ for sorghum flour. A negative correlation, though weak $(\mathrm{r}=-0.23)$ also existed between amylase yield and final media $\mathrm{pH}$. This also suggests that $\mathrm{pH}$ might have played a vital role in the significant $(\mathrm{P}<0.01)$ interaction of the different concentrations of sorghum flour and a mixture of $\left(\mathrm{NH}_{4}\right)_{2} \mathrm{SO}_{4}+$ soybean meal on amylase production.

The production of $\alpha$-amylase is very sensitive to initial $\mathrm{pH}$ of the fermentation medium. Enzyme production increased as the initial medium $\mathrm{pH}$ increased from $3-5$ (Figure 1). Between $\mathrm{pH} 5$ - 7, there were no differences in enzyme yields, however, a sharp increase was observed at $\mathrm{pH} 8$, beyond which amylase production dropped. The amylase yield at this optimal $\mathrm{pH}$ was $0.463 \mathrm{U} / \mathrm{ml}$ and the final media $\mathrm{pH}$ was 5.27 . This yield was however not 
ORJI, J. C.; NWEKE, C. O.; NWABUEZE, R. N.; NWANYANWU, C. E.; ALISI, C. S.; ETIM-OSOWO, E. N. Production and properties of $\alpha$-amylase from Citrobacter species. Ambi-Agua, Taubaté, v. 4, n. 1, p. 45-57, 2009. (doi:10.4136/ambi-agua.73)

significantly different $(\mathrm{P}>0.01)$ from $0.392 \mathrm{U} / \mathrm{ml}$ obtained at $\mathrm{pH} 9.0$. Hence the organism required a slightly alkaline environment for optimal amylase production. Also in line with the previous observations (Tables 1 and 2), as the amylase yield started declining, the final media $\mathrm{pH}$ started rising. Reports on the optimal $\mathrm{pH}$ for amylase production by microbes are varied. UI Qader et al. (2006) reported optimal amylase production by Bacillus sp AS-1 at pH 7.0 while Kiran et al. ( 2005) observed that in Bacillus licheniformis TCRDC-B13, amylase synthesis drastically dropped as $\mathrm{pH}$ was increased to 8.5 .

Table 2. Effects of different concentrations of sorghum flour and $\left(\mathrm{NH}_{4}\right)_{2} \mathrm{SO}_{4}+$ soybean meal on amylase production.

\begin{tabular}{cccccc}
\hline \multirow{2}{*}{$\begin{array}{c}\text { Sorghum } \\
\text { flour } \\
\text { (\% w/v) }\end{array}$} & $\mathbf{5 . 5}$ & $\mathbf{4}$ & \multicolumn{4}{c}{ Amylase activity (U/ml) } & \multirow{2}{*}{ Mean } \\
\cline { 2 - 5 } & $\mathbf{0 . 5}$ & $\mathbf{1 . 5}$ & $\mathbf{2 . 0}$ & \\
\hline 0.5 & $0.107(4.54)$ & $0.160(5.08)$ & $0.107(4.92)$ & $0.071(4.93)$ & $0.111(4.87)$ \\
1.0 & $0.053(4.83)$ & $0.294(4.79)$ & $0.214(4.63)$ & $0.178(4.87)$ & $0.185(4.78)$ \\
2.0 & $0.249(4.51)$ & $0.285(4.59)$ & $0.427(4.68)$ & $0.321(4.74)$ & $0.321(4.63)$ \\
3.0 & $0.071(4.57)$ & $0.107(4.65)$ & $0.249(4.64)$ & $0.214(4.86)$ & $0.160(4.68)$ \\
Mean & $0.120(4.61)$ & $0.212(4.65)$ & $0.250(4.64)$ & $0.178(4.86)$ & $0.190(4.74)$ \\
\hline
\end{tabular}

Basal medium contains Sorghum flour and $\left(\mathrm{NH}_{4}\right)_{2} \mathrm{SO}_{4}+$ Soy bean meal at the stated concentrations. Initial media $\mathrm{pH}=6.0$; Figures in parenthesis are final media $\mathrm{pH}$

$L S D_{0.01}$ for Sorghum flour concentration $=0.014$

$L S D_{0.01}$ for $\left(\mathrm{NH}_{4}\right)_{2} \mathrm{SO}_{4}+$ Soybean meal $=0.014$

$L S D_{0.01}$ for means of different concentrations of Sorghum flour at the same or different concentrations of $\left(\mathrm{NH}_{4}\right)_{2} \mathrm{SO}_{4}+$ Soybean meal $=0.027$

Time course for amylase production shows that the highest yield of enzyme $(0.499 \mathrm{U} / \mathrm{ml})$ was obtained after $60 \mathrm{~h}$ of incubation. (Figure 2). Beyond $60 \mathrm{~h}$, drastic reduction in yield was obtained probably due to the production of secondary metabolites that are inhibitory to enzyme synthesis. Although biomass was not monitored in this study, this view is accentuated by previous reports on microbial amylase production which showed enzyme production accompanying exponential growth and continuing into the stationary phase where the production of other metabolites inhibited enzyme production (Obineme et al., 2003; Fossi et al., 2005). Kiran et al., 2005 also reported maximum enzyme production by a thermophilic Bacillus sp. K12 after $60 \mathrm{~h}$ incubation using starch as the carbon source.

Characterization of the crude enzyme showed that the enzyme was maximally active at $60^{\circ} \mathrm{C}$, retaining $100 \%$ of its original activity at $60^{\circ} \mathrm{C}$ for $2 \mathrm{~h}$ and over $65 \%$ at $70^{\circ} \mathrm{C}$ for $3 \mathrm{~h}$ (Figures 3 and 4). High thermostability is a desirable attribute for amylases suitable for use in high temperature fermentations such as the gelatinization of starch. High processing temperatures also limit the growth of mesophilic contaminants in fermentation processes and ensure the generation of effluents with more uniform characteristics, which would be easier to dispose. The crude $\alpha$-amylase of the Citrobacter sp. has a comparable temperature activity range with that of Bacillus sp reported by Teodoro and Martins (2000) but was however less stable. 


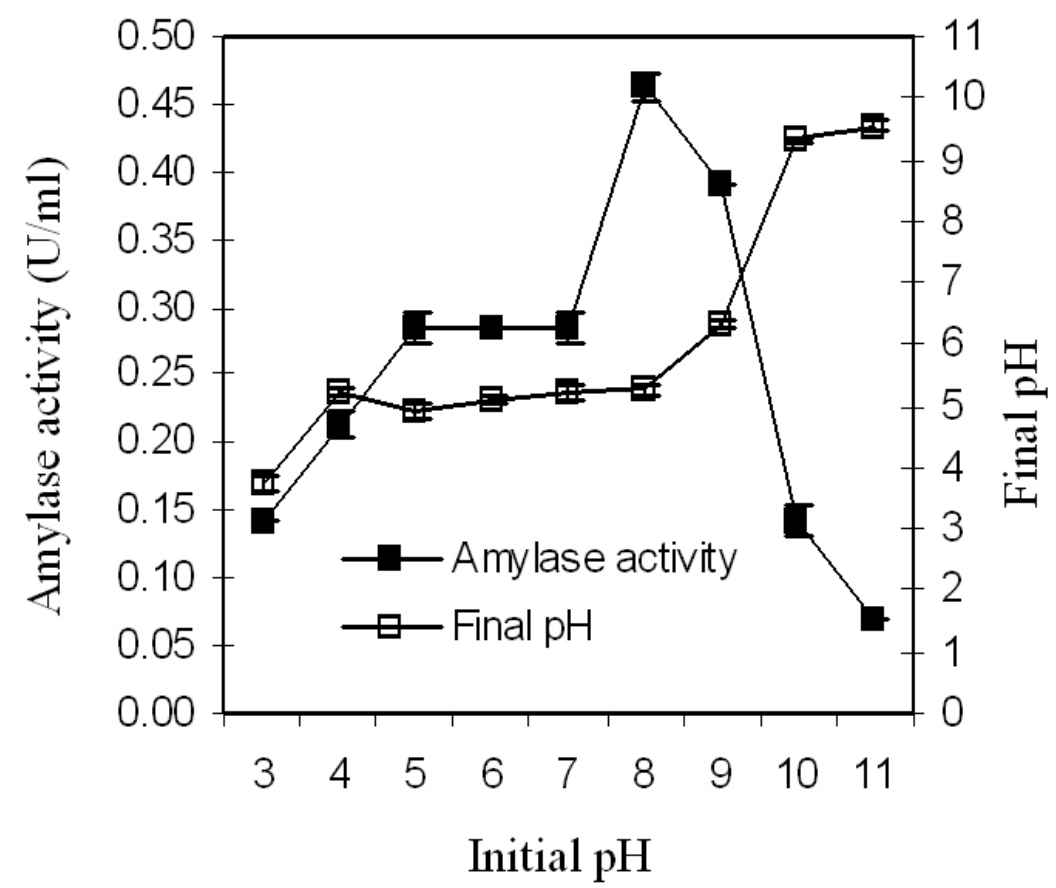

Figure 1. Effects of initial $\mathrm{pH}$ of medium on amylase production by Citrobacter species. (Basal medium contains sorghum flour $(2.0 \% \mathrm{w} / \mathrm{v})$ and a mixture of $\left(\mathrm{NH}_{4}\right)_{2} \mathrm{SO}_{4}+$ soybean meal $(1.5 \%$ $\mathrm{w} / \mathrm{v})$.

The $\mathrm{pH}$ activity and stability profiles of the organism showed that at a $\mathrm{pH}$ range of $3-6$, there was no appreciable difference in amylase activity. However, at $\mathrm{pH} 7$ a sharp increase in amylase activity was observed and this declined thereafter. Also, the enzyme maintained $100 \%$ of its original activity at $\mathrm{pH} 9-10$ for 2 hours at room temperature $\left(28+2^{\circ} \mathrm{C}\right)$ (Figure 5 ). Since the amylase was optimally produced at an initial medium $\mathrm{pH}$ of $8-9$, had optimal activity at $\mathrm{pH} 7.0$ and retained maximum activity at $\mathrm{pH} 9-10$, this strain of Citrobacter $\mathrm{sp}$ would survive under neutral to slightly alkaline environments. Pandey et al. (2000) noted that the fundamental characteristics of extracellular amylases reflect the $\mathrm{pH}$ of the environment in which the organisms are grown. The enzyme resembles that of a strain of alkaliphilic Bacillus sp. which grew best at $\mathrm{pH} 8.5$ and produced an $\alpha$-amylase which had a $\mathrm{pH}$ optimum of 9.0 (Lin et al., 1998). Also for Bacillus sp AS-1, optimal amylase production was at $\mathrm{pH} 7.0$, and optimal activity was obtained at pH 7.5 (UI Qader et al., 2006).

Significant $(\mathrm{P}<0.01)$ stimulatory effects on amylase activity were observed with various cations $\left(\mathrm{Mg}^{2+}, \mathrm{Ca}^{2+}, \mathrm{Zn}^{2+}, \mathrm{Co}^{2+}, \mathrm{Ba}^{2+}, \mathrm{K}^{+}, \mathrm{Na}^{+}, \mathrm{Fe}^{2+}, \mathrm{Ni}^{2+}\right)$ (Table 3). This suggests that metal ions are essential for the activity of the $\alpha$-amylase from Citrobacter $\mathrm{sp}$. The cations protect the enzyme from heat denaturation and contribute to thermostability (Forgaty and Kelly, 1980). The effect of enzyme modulators showed that urea was stimulatory, $\mathrm{HgCl}_{2}$ inhibitory while EDTA had no effect (Table 3). The inactivation of the enzyme by $\mathrm{HgCl}$ suggests that the enzyme require reduced thiol groups for activity since $\mathrm{Hg}^{2+}$ has been reported to have a very high affinity for thiol groups (Nies, 1999). With respect to the effects of the divalent cations $\mathrm{Mg}^{2+}, \mathrm{Ca}^{2+}, \mathrm{Co}^{2+}, \mathrm{K}^{+}$and $\mathrm{Fe}^{2+}$, and responses to the modulators, $\mathrm{HgCl}$ and EDTA, the extracellular amylase from Citrobacter sp differs from that of Thermus sp (Shaw et al., 1995). 
ORJI, J. C.; NWEKE, C. O.; NWABUEZE, R. N.; NWANYANWU, C. E.; ALISI, C. S.; ETIM-OSOWO, E. N. Production and properties of $\alpha$-amylase from Citrobacter species. Ambi-Agua, Taubaté, v. 4, n. 1, p. 45-57, 2009. (doi:10.4136/ambi-agua.73)

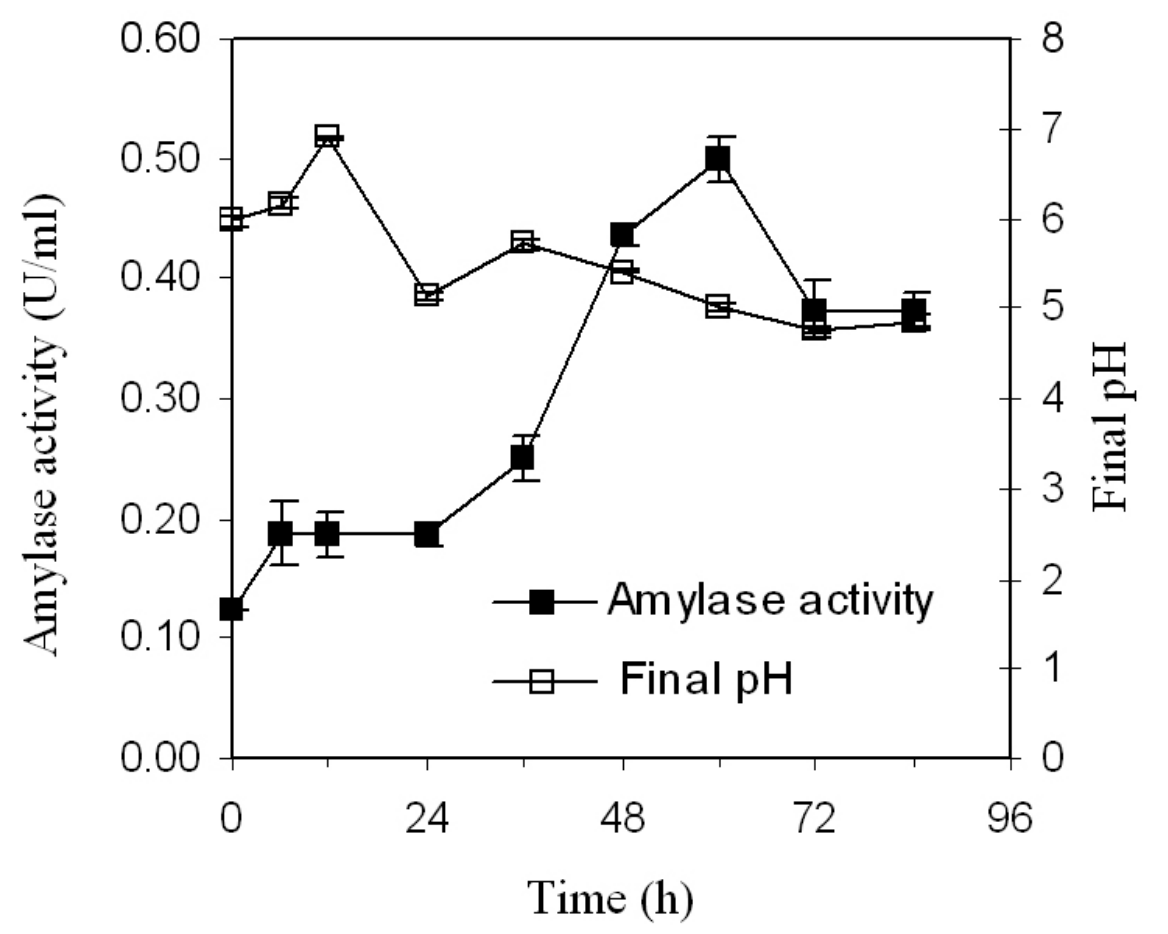

Figure 2. Time course for amylase production by Citrobacter species (Basal medium contains sorghum flour $(2.0 \% \mathrm{w} / \mathrm{v})$ and a mixture of $\left(\mathrm{NH}_{4}\right)_{2} \mathrm{SO}_{4}+$ soybean meal $(1.5 \% \mathrm{w} / \mathrm{v})$, Initial $\left.\mathrm{pH} 8.0\right)$.

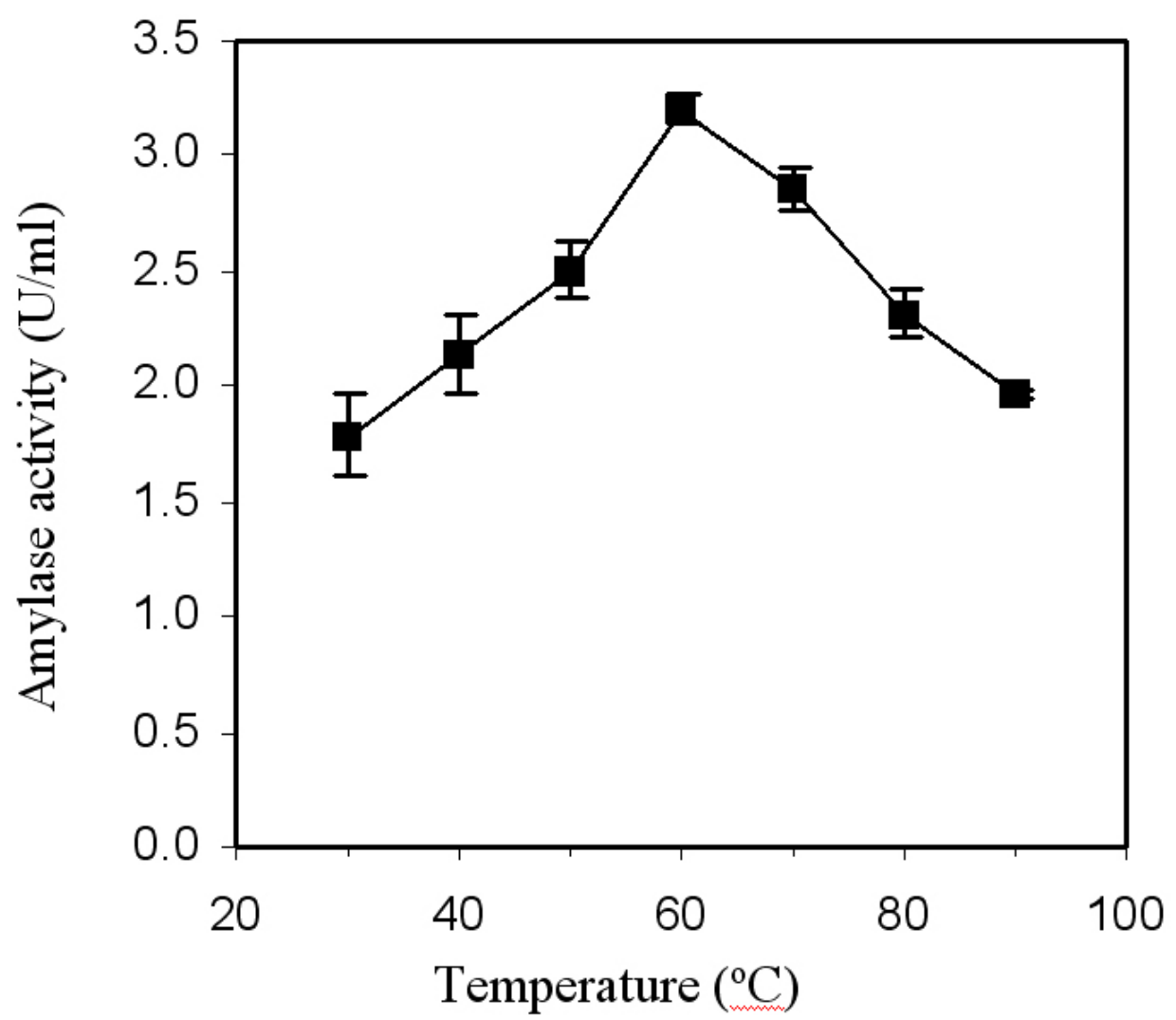

Figure 3. Effects of temperature on amylase activity. 
ORJI, J. C.; NWEKE, C. O.; NWABUEZE, R. N.; NWANYANWU, C. E.; ALISI, C. S.; ETIM-OSOWO, E. N. Production and properties of $\alpha$-amylase from Citrobacter species. Ambi-Agua, Taubaté, v. 4, n. 1, p. 45-57, 2009. (doi:10.4136/ambi-agua.73)

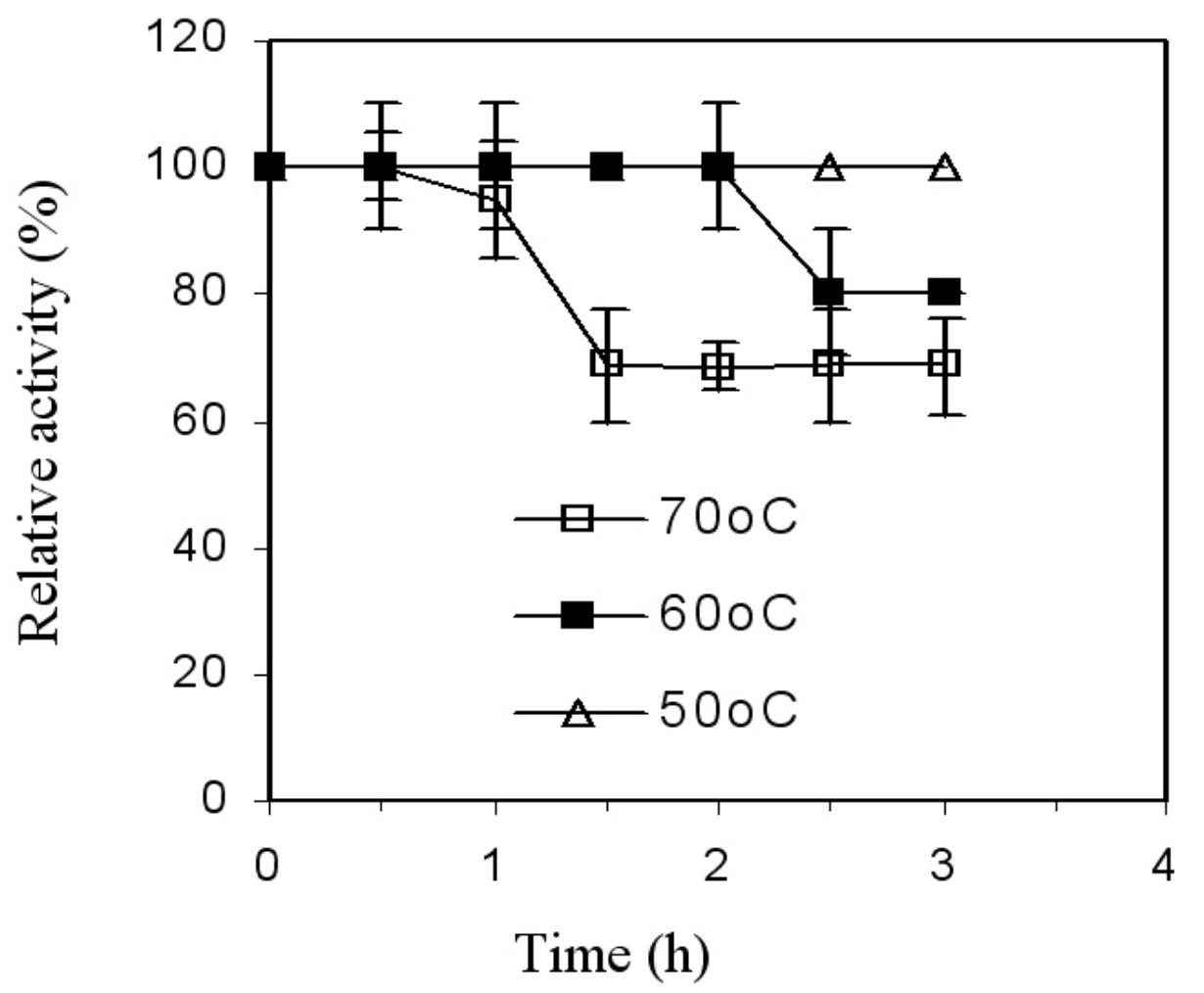

Figure 4. Thermal stabilities of the amylase enzyme at 50,60 and $70^{\circ} \mathrm{C}$.

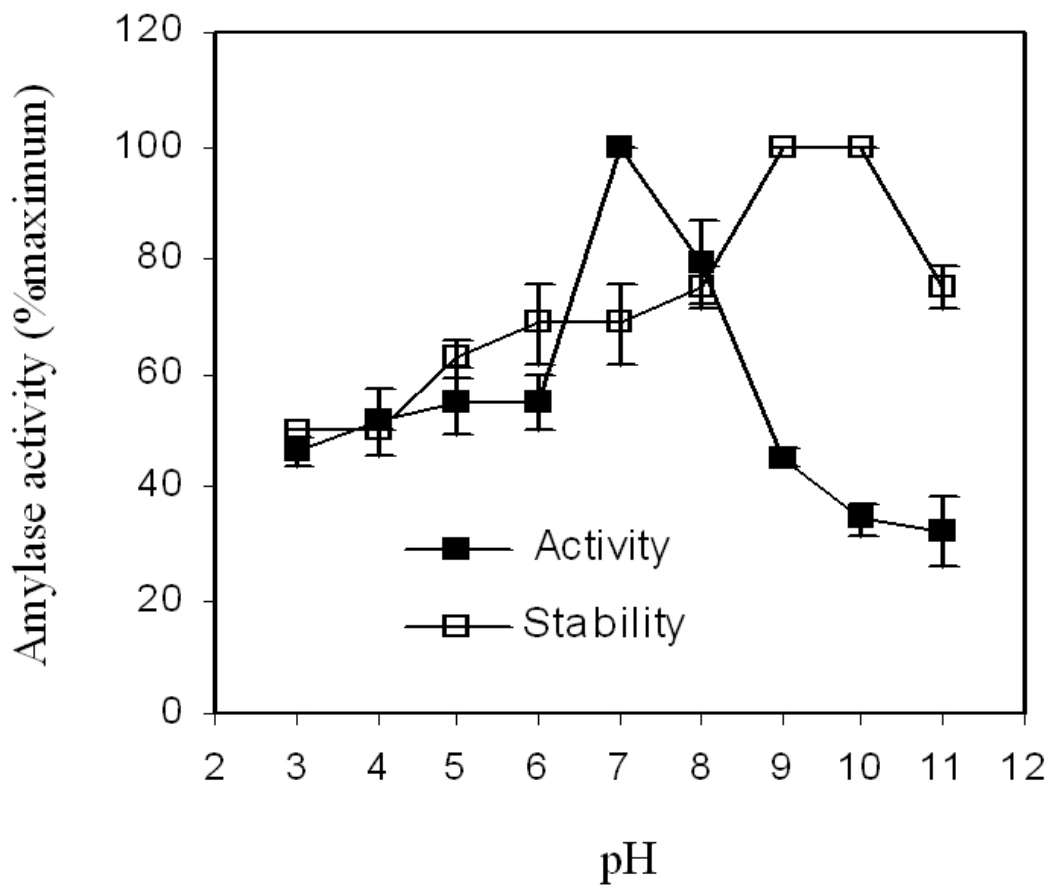

Figure 5. Effects of $\mathrm{pH}$ on amylase activity and stability. 
ORJI, J. C.; NWEKE, C. O.; NWABUEZE, R. N.; NWANYANWU, C. E.; ALISI, C. S.; ETIM-OSOWO, E. N. Production and properties of $\alpha$-amylase from Citrobacter species. Ambi-Agua, Taubaté, v. 4, n. 1, p. 45-57, 2009. (doi:10.4136/ambi-agua.73)

Table 3. Effects of metal ions and enzyme modulators on amylase activity.

\begin{tabular}{cc}
\hline $\begin{array}{c}\text { Metal ions/ } \\
\text { Enzyme modulators }\end{array}$ & $\begin{array}{c}\text { Relative } \\
\text { Activity (\%) }\end{array}$ \\
\hline $\mathrm{Control}^{2+}$ & $100.00 \pm(0.00)$ \\
$\mathrm{Ca}^{2+}$ & $123.45 \pm(3.65)$ \\
$\mathrm{Zn}^{2+}$ & $163.25 \pm(28.25)$ \\
$\mathrm{Co}^{2+}$ & $125.92 \pm(9.24)$ \\
$\mathrm{Ba}^{2+}$ & $163.40 \pm(32.88)$ \\
$\mathrm{K}^{+}$ & $125.92 \pm(29.24)$ \\
$\mathrm{Na}^{+}$ & $138.68 \pm(23.64)$ \\
$\mathrm{Fe}^{2+}$ & $120.14 \pm(11.38)$ \\
$\mathrm{Urea}^{2+}$ & $133.92 \pm(17.44)$ \\
$\mathrm{Ni}^{2+}$ & $123.15 \pm(13.18)$ \\
$\mathrm{EDTA}$ & $146.48 \pm(29.78)$ \\
$\mathrm{Hg}^{2+}$ & $100.17 \pm(21.73)$ \\
\hline
\end{tabular}

Note: Figures in parenthesis are standard deviations from the means).

\section{CONCLUSION}

The ability to produce a thermostable $\alpha$-amylase at mesophylic temperature would lower production cost and lend the organism, Citrobacter sp. economical for industrial exploitation. Its use will eliminate mesophylic contaminants in the production process and ensure generation of effluents, which would be easier to dispose. Furthermore, the non-inhibitory effect of the enzyme by various inorganic chemicals implies that the Citrobacter sp. amylase would find use in industries where these metals pose problems either in the production process or in waste treatment facilities. All these are desirable attributes, which could equally be engineered into another organism to improve amylase activity and engender industrial sustainability.

\section{ACKNOWLEDGEMENT}

The authors express their heartfelt gratitude to Dr Ogoke of the Department of Crop Science and Technology, Federal University of Technology, Owerri for the statistical analysis.

\section{REFERENCES}

BERNFELD, P. Amylases $\alpha$ and $\beta$. Methods Enzymol, v. 1, p.149-158, 1955.

BOLTON, D. J.; KELLY, C. T.; FOGARTY, W. M. Purification and characterization of the $\alpha$-amylase of Bacillus flavothermus. Enz. Microbial Technol, v. 20, p. 340-343, 1997.

CAMPBELL, D. H.; GARVY, S. J.; CREMER, N. E.; SUSSDERF, D. H. Methods in immunology. A laboratory test for instruction and research . 2. ed. New York: W. A. Benjamin, 1970. , p. 475.

FORGATY, W. M.; KELLY, C. T. Microbial enzymes and bioconversions: amylases. New York: Academic Press, 1980. p.115-170. 
FOSSI, B. T.; TAVEA, F.; NDJOUENKEU, R. Production and partial characterization of a thermostable amylase from Ascomycetes yeast strain. Afr. J. Biotechnol, v. 4, p. 14-18, 2005 .

GENSTAT. GenStat for Windows Release 4.24DE Discovery edition. Hemel Hempstead: VSN International, 2005.

HAQ, I.; ABDULLAH, R.; ASHRAF, H.; SHAH, A. Isolation and screening of fungi for the biosynthesis of alpha amylase. Biotechnol., v. 1, p. 61-66, 2002.

HOLT, J. G.; KRIEG, N. R.; SNEATH, P. H. A.; STAlEY, J. T.; WILliAMS, S. T. Bergey's Manual of Determinative Bacteriology. 9. ed. Baltimore: Williams, Wilkins, 1994.

ILORI, M. O.; AMUND, O. O.; OMIDIJI, O. Effect of carbon and nitrogens sources on glucoamylase production in Lactobacillus brevis. Folia Microbiol., v. 41, p. 339-340, 1996.

KIRAN, O. I.; COMLEKCIOGLU, U. I.; ARIKAN, B. Effects of carbon sources and various chemicals on the production of a novel amylase from a thermophilic Bacillus sp. K-12. Turk. J. Biol., v. 29, p. 99-103, 2005.

LAU, P. C. K.; JAWORSKI, J. F. Industrial sustainability through biotechnology. Biotechnology Industry Organization. ASM News 69 (3):111, 2003.

LIN, L. L.; CHYAU, C. C.; HSU, W. H. Production and properties of a raw-starch-degrading amylase from thermophilic and alkaliphilic Bacillus sp. TS-23. Biotech. Appl. Biochem., v. 28, p. 61-68, 1998.

NIES, D. H. Microbial heavy-metal resistance. Appl. Microbiol. Biotechnol., v. 51, p. 730$750,1999$.

OBINEME, O. J.; EZEONU, I. M.; MUONEKE, A. N.; OBI, S. K. C. Production and characterization of an $\alpha$-amylase from an Aspergilus oryzae isolated from soil. Nig. $\mathbf{J}$. Microbiol., v. 17, p.71-79, 2003.

ORGANISATION FOR ECONOMIC CO-OPERATION AND DEVELOPMENT - OECD . The application of biotechnology for industrial sustainability. 2001. Available: $<$ http://www1.oecd.org/publications/e-book/9301061e.pdf $>$. Access: 20 February, 2009.

PANDEY, A.; NIGAM, P.; SOCCOL, C. R.; SOCCOL, V. T.; SINGH, D.; MOHAN, R. . Advances in microbial amylases. Biotechnol. Appl. Biochem., v. 31, p. 135-152, 2000.

SHAW, J. F.; LIN, F. P.; CHEN, C. H. Purification and properties of an extracellular alphaamylase from Thermus sp. Bot. Bull. Acad. Sin., v. 36, p.1, 1995.

TEODORO, C. E. S.; MARTINS M. L. L. Culture conditions for the production of thermostable amylases by Bacillus sp. Braz J. Microbiol., v. 31, p. 1-9, 2000.

UGURU, G. C.; ROBB, D.; AKINYANJU, J. A.; SAM, A. Purification, characterization and mutagenic enhancement of a thermoactive a-amylase from Bacillus subtilis. J. Ind. Microbiol. Biotechnol., v.19, p. 273-279, 1997. 
ORJI, J. C.; NWEKE, C. O.; NWABUEZE, R. N.; NWANYANWU, C. E.; ALISI, C. S.; ETIM-OSOWO, E. N. Production and properties of $\alpha$-amylase from Citrobacter species. Ambi-Agua, Taubaté, v. 4, n. 1, p. 45-57, 2009. (doi:10.4136/ambi-agua.73)

UI QADER, S.; BANO, S.; AMAN, A.; SYED, N.; AZHAR, A. Enhanced production and extracellular activity of commercially important amylolytic enzyme by a newly isolated strain of Bacillus. sp. AS-1. Turk J Biochem., v. 31, n. 3, p. 135-140, 2006.

YOON, M. Y. Denim finishing with enzymes. 2005. Dyer International, v. 11: 16-19, 2005. 